\title{
VÖLGYEK ÉS LINEAMENSEK KAPCSOLATA A SZERKEZETI ELEMEKKEL A BÜKK DÉLNYUGATI ELÖTERÉBEN
}

\author{
Pecsmány Péter \\ PhD hallgató, Miskolci Egyetem, Természetföldrajz-Környezettan Intézeti Tanszék \\ 3515 Miskolc, Miskolc-Egyetemváros, e-mail: ecopeter@uni-miskolc.hu \\ Hegedüs András \\ egyetemi docens, Miskolci Egyetem, Természetföldrajz-Környezettan Intézeti Tanszék \\ 3515 Miskolc, Miskolc-Egyetemváros, e-mail: ecoeged@uni-miskolc.hu
}

\begin{abstract}
Absztrakt
A hazai és a nemzetközi szakirodalomban is találkozhatunk a völgyek és lineamensek tektonikus eredetének vizsgálatával. Jelen munka a Bükk délnyugati elöterének szerkezeti elemei és a domborzatban megjelenö lineáris elemek (völgyek, lineamensek) közötti kapcsolatot próbálja meg feltárni. A vizsgálat során terepen észlelt szerkezetek és a földtani térképeken jelölt (térképezett) szerkezeti elemek csapásirányát hasonlitottuk össze a környezetükben futó völgyek és lineamensek irányával.
\end{abstract}

Kulcsszavak: völgyhálózat, lineamens hálózat, szerkezeti elemek, összehasonló elemzés, Bükk

\begin{abstract}
The tectonic preformation of valleys and lineaments can also be found in the literature. The present work attempts to explore the relationship between the geological structural elements of the southwestern Bükk foreland and the linear elements (valleys, lineaments) appearing in the topography. During the study, the impact strike of the structures observed in the field and the mapped structural elements are compared with the direction of the valleys and lineaments in their surroundings.
\end{abstract}

Keywords: drainage network, lineaments, faults, comparative analysis, Bükk Mts.

\section{Bevezetés}

A hazai és a nemzetközi szakirodalomban egyaránt találkozhatunk a domborzatban megjelenő lineáris elemek tektonikus eredetének vizsgálatával. A cikkek egy része pusztán módszertani fejlesztéseket közöl, másik része pedig regionális léptékben von le szerkezetföldtani következtetéseket [1-5].

A Bükkvidék közel másfél évszázadnyi földtani és geomorfológia térképezése során születtek olyan fővölgyekre vonatkozó megállapítások, melyek szerint a Tárkányi-, az Eger-, az Ostoros-, a Kánya-, a Hór-, a Kácsi- és a Kulcsárvölgyi-patak egyes szakaszai szerkezetileg előrejelzett völgyben futnak [6-10], azonban részletes vizsgálatuk még nem történt meg.

Munkánk célja az volt, hogy a Bükk hegység délnyugati előterében elemezzük a földtani szerkezeti elemek és a domborzatban megjelenő lineáris elemek közötti kapcsolatot.

\section{Anyag és módszer}

A terepbejárások során mikrotektonikai észleléseket végeztünk. A vetők és litoklázisok iránymérését (dőlés, csapás) Freiberg-típusú geológuskompasz és FieldMove Clino IOS mobilalkalmazás segítségé- 
vel végeztük el, 13 feltárásban/bányában (1. ábra). A mért adatokat a deklináció értékével nem korrigáltuk. A mért csapásirány értékeket használtuk fel az aljazszerkezet formakincsre gyakorolt hatásának vizsgálata során. Fontos megemlítenünk, hogy egy-egy párhuzamos kőzetrésrajra vonatkozó mérések számát jelentősen befolyásolhatja a feltárás kitettsége (pl.: egy K-Ny-i csapású bányafal/útbevágás sokkal több É-D-i irányú kőzetrést tár fel, mint K-Ny-it, még akkor is, ha azok a területen közel azonos számban fordulnak elö), tehát az iránygyakoriság elemzése során nem csak a leggyakoribb irányt, hanem a vető-/kőzetrésrajok irányát is érdemes figyelembe venni.

Ezt követően a terepi észlelések $2 \mathrm{~km}$-es sugarú környékén belül vetettük össze a mért és a földtani térképeken ábrázolt (a továbbiakban: térképezett) szerkezeti elemek csapásirányát a völgyek és lineamensek futásának irányával.

Az ismert vetőket Less Gy. és mtsi. [9] és Petrik A. [10] földtani/szerkezetföldtani térképeiröl digitalizáltuk be (1. ábra).

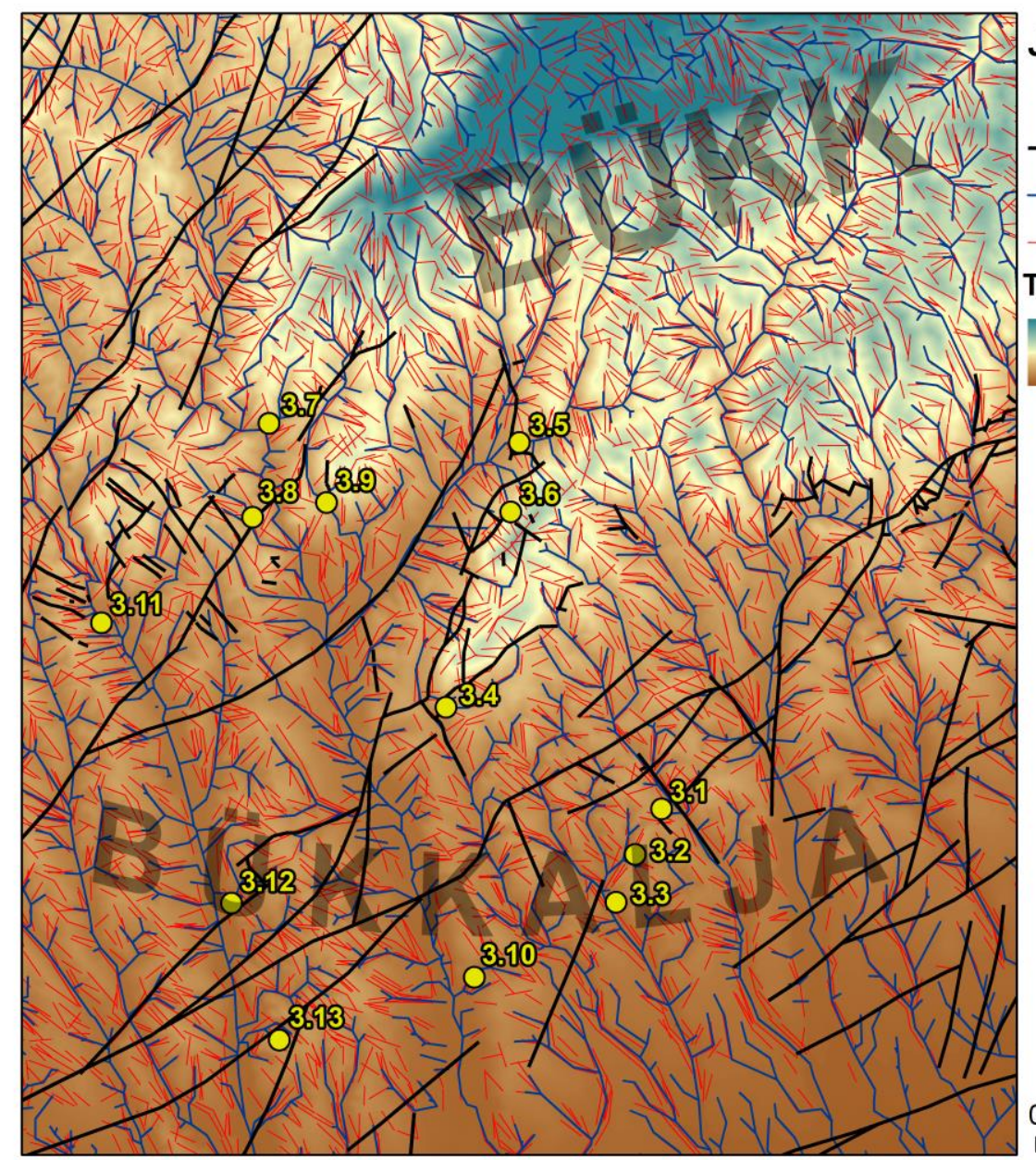

\section{Jelkulcs}

Terepi észlelések helyei

Vetök/szerkezeti elemek

- Völgyhálózat

Tineamensek
Tszf-i magasság $(\mathrm{m})$

958

85

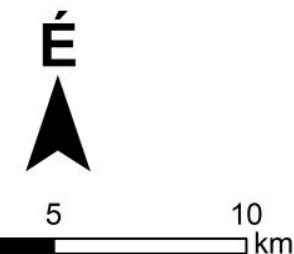

1. ábra. A terület elhelyezkedése, a terepi észlelések helyei a szerkezeti és lineáris elemekkel.

A völgyhálózat meghatározása 25 m-es terepi felbontású digitális terepmodellből (HydroDEM) származtatott elméleti vízfolyáshálózat alapján történt. Az elméleti vízfolyáshálózat számítása során 
$200 \mathrm{~m}^{2}$-es kritikus forrásterülettel számoltunk. A kapott állományt vizuális kiértékelés alapján javítottuk: a széles, lapos völgytalpakon megjelenő párhuzamos vízfolyásokból völgyenként csak egyet hagytunk meg. A javított állományt generalizáltuk, elsimítva a kisebb lokális léptékủ (100 m) változásokat (szakaszokat). Erre azért volt szükség, hogy a völgyirányokba jelentkezö 5-10 fokos kilengéseket kiegyenlítsük, hiszen ezek pusztán a mederváltozás útján is kialakulhattak [4] (1. ábra).

A lineamensek detektálásához Al-Obeidat, F. és mtsi. [11] módszerét használtuk fel, akik digitális terepmodellből származtatott árnyékolt domborzatmodellen (Hillshade) a képfeldolgozásnál használt Canny éldetektáló algoritmust alkalmazták. Mivel az árnyékolt terepmodellen végzett vizsgálatok nagyban függnek a megvilágítás irányától, ezért két ellentétes irányból $\left(45^{\circ}, 315^{\circ}\right)$ készítettük el az árnyékolt terepmodellt (Hillshade). Ezt követően a kapott állományokat MatLab szoftveres környezetbe importáltuk, ahol elvégeztük a cikkben megadott algoritmus szerinti élkeresést. Ezt követően az eredmény raszteres állományokat ArcGIS-be helyeztük, majd vektorizáltuk. Ebben az esetben is elvégeztük a kapott állományok generalizálását, majd a két megvilágítási irányból származó lineamens térképeket egy állománnyá egyesítettük. Ezt követően a lineamenseken szürést végeztünk el, mely segítségével az automatikus vektorizálásból származó apróbb hibákat próbáltuk javítani. Ezek után az iránystatisztikai vizsgálat során már csak az 500 m-nél hosszabb lineamenseket vettük figyelembe, azt feltételezve, hogy az ennél rövidebb geomorfológiai elemek kisebb valószínüséggel kötődhetnek szerkezeti elemekhez (1. ábra).

A mért csapásirányokat, a térképezett szerkezeti elemeket, valamint a völgyek és lineamensek irány- és hosszirány gyakoriságát RockWorks 16 szoftver segítségével, $10^{\circ}$-os beosztásközzel rózsadiagramon ábrázoltuk. A mért szerkezeti elemek sürüségi sztereogramját StereoNet 10.4.6-ban készítettük el.

\section{Feltárások elemzése}

\subsection{Szomolya - pincesor}

A Kánya-patak Ny-i völgyközi hátán található borospincék horzsaköves, freatomagmás riolittufába (Gyulakeszi Riolittufa Formáció) mélyülnek [9,12]. Petrik A. [10] a szomolyai kaptárkövek környékén többnemzedékü, K-Ny-i irányú jobbos eltolódásokat, a szintén közeli Ispán-hegy (középső-) dácittufájában szintén $\mathrm{K}-\mathrm{Ny}$-i irányú konjugált normálvetöket észlelt. A pincesor $2 \mathrm{~km}$-es környékén ÉNyDK-i, és erre merőleges irányú, ÉK-DNy-i csapású szerkezeti elemeket térképeztek $[9,10]$.

A pincék környékén É-D-i és ÉÉK-DDNy-i csapásirányú kőzetréseket észleltünk. Az utóbbi közetrés csoport $\sim 20^{\circ}$-os irányszög változékonysággal rendelkezik (2. ábra).

A völgyek és lineamensek nagyrészt ÉNy-DK-i irányba futnak. A lineamenseknél elkülöníthető még egy kevésbé jelentős ÉK-DNy-i irány, mely a völgyek hosszirány gyakorisága esetében jelentős mellékirányként jelenik meg (2. ábra).

A völgyek és lineamensek leggyakoribb iránya jól követi a térképezett szerkezetek modális csapásirányát, a mért szerkezeti elemek csapásirányával nincs kapcsolat.

\subsection{Pipis-tető}

A Novaji- és a Kánya-patak közös völgyközi hátán található Pipis-tetőn mélyített kőfejtők jól összesült ignimbritet (Tari Dácittufa Formáció) tárnak fel [9, 12]. Egyik kőfejtő jelenleg is bejárható volt, ahol a szerkezetföldtani észleléseket végeztünk. A kőfejtő 2 km-es környékén ÉNy-DK-i csapású szerkezeti elemeket térképeztek $[9,10]$. 
A mért szerkezeti elemek csapásirányai meglehetősen nagy szórással rendelkeznek. A szerkezeti elemek a rózsadiagram alapján nagyrészt NyÉNy-KDK-i csapásúak, azonban ha megnézzük a sürüségi sztereogram kontúrjait, akkor ez az érték ÉNy-DK-i irány felé tolódik el (2. ábra).

A völgyek és a lineamensek mind irány-, mind pedig hosszirány gyakoriság esetében nagyrészt ÉNy-DK-i irányba futnak. A völgyek esetében megfigyelhetünk még egy jelentösebb ÉK-DNy-i mellékirányt (2. ábra).

A völgyek és lineamensek modális iránya jól követi a területen térképzett ÉNy-DK-i csapású szerkezeti elemeket. A terepen mért töréses szerkezeti elemekkel való kapcsolat, az adatok előzőek során említett bizonytalansága miatt megkérdőjelezhető.

\subsection{Novaj - Homokbánya}

A Novajtól ÉK-re található homokbánya pannon korú, osztályozott, keresztrétegzett, durva és finomszemcsés homokkövet, durva kavicsos homokövet és aleurit rétegeket tár fel. A bányában Petrik A. [10] K-Ny-i csapásirányú normálvetőket észlelt. A feltárás 2 km-es környékén ÉÉK-DDNy-i csapásirányú vetőket térképeztek $[9,10]$.

A bányában Petrik A.-hoz [10] hasonlóan mi is K-Ny-i irányú konjugált normálvetőket, illetve ÉK-DNy-i csapású normálvetőket észleltünk. A bányában a rétegek D-i irányba $\sim 8^{\circ}$-kal vannak kibillenve (2. ábra).

A völgyek iránygyakoriság alapján nem mutatnak irányítottságot, hosszirány gyakoriság alapján zömében EK-DNy-i irányúak, azonban egy ÉNy-DK-ies irány is markánsan megjelenik. A lineamensek leggyakoribb iránya mind a két esetben ÉNy-DK-i, illetve elkülöníthető még egy erre merőleges, de kevésbé jelentős ÉK-DNy-i irány (2. ábra).

A völgyek hosszirány gyakoriságának legjellemzőbb értéke a térképezett és az általunk mért ÉNyDK-i csapásirányú szerkezeti elemekhez áll közel, a néhány fokos eltérést a kőzetminőség megváltozásával lehet magyarázni [4]. A lineamensek legjellemzőbb iránya és a szerkezeti elemek között nincs kapcsolat.

\subsection{Kis-Eged-hegy - Noszvaji útbevágás}

Egerből a Vécsey-völgyön keresztül Noszvaj felé vezető út mentén, a Kis-Eged-hegy D-i és DK-i oldalába számos kisebb-nagyobb feltárást találhatunk. A feltárások a késő-eocéntól (priabónai korszak) és késő-oligocénig terjedő rétegeket tárnak fel [13]. A méréseket a növénymaradványairól híres lemezes márga, agyagkő (Tardi Agyag Formáció) egyik feltárásában végeztük. Petrik A. [10] megemlíti, hogy a közeli eocén mészkőben Fodor L - Bordás R. ÉK-DNy-i csapású konjugált rátolódásokat és ferde jobbos rátolódásokat észlelt (nem publikált adatok), Petrik A. [10] ezeket a rátolódásokat észlelte a kis-egedi oligocén agyagkőben. A feltárásban kisebb gyürődéseket is megfigyelt, ezeket mi is azonosítottuk terepen. Ezen kívül még ÉNy-DK-i csapású konjugált kőzetréseket észlelt. A feltárás 2 km-es környékén nagyobb részt ÉK-DNy-i és ÉÉK-DDNy-i csapásirányú szerkezeti elemeket térképeztek $[9,10]$.

A feltárásnál - hasonlóan Petrik A.-hoz [10] - zömében ÉNy-DK-i és ÉÉNy-DDK-i csapásirányú konjugált kőzetréseket észleltünk, nagyjából $\sim 40^{\circ}$-os irányszögingadozással. A rétegek átlagosan $\sim 29^{\circ}$-kal $\sim$ K, DK-i irányba vannak kibillenve (2. ábra).

A völgyek iránygyakoriság alapján zömében ÉK-DNy-i irányúak, míg hosszirány tekintetébe irányítatlan a völgyhálózat. A lineamensek mind a két esetben javarészt K-Ny-i irányúak, mellékirányok közül az ÉNy-DK-i irányt lehet megemlíteni, amely a hosszirány gyakoriság esetében válik jelentösebbé (2. ábra). 
A völgyek szerkezeti elemekkel való kapcsolata csak a gyakoriság esetében lehet mérvadó, de a hosszirány gyakoriságban jelentkező irányítatlanság ezt megcáfolja. A lineamensek esetében a modális irányok nem, csak az ÉNy-DK-i mellékirány kapcsolható a terepen mért kőzetrések csapásirányához.

\subsection{Felsőtárkány - Mészkőszurdok}

A Tárkányi-patak közvetlenül a medencébe való érkezése elött, a Barát-völgy szurdokában töri át az alaphegység mészkövét. A szük völgy biogén, zátony és ciklikus lagúna környezetben képződött középső-triász (karni-ladin) korú mészkövet (Bervai Mészkő Formáció) tár fel [9]. A szurdok 2 km-es környékén ÉÉK-DDNy-i csapású vetők ismertek [9, 10].

A szurdokvölgyben nagyrészt $\mathrm{K}-\mathrm{Ny}$-i csapásirányú töréseket észleltünk, mely raj $\mathrm{kb} \sim 50^{\circ}$-os irányszög ingadozást mutat (2. ábra).

A völgyek iránygyakoriság alapján ÉK-DNy-i, míg hosszirány gyakoriság esetében ÉNy-DK-i irányba futnak. Iránygyakoriság alapján jelentős mellékirányként jelenik meg a $\mathrm{K}-\mathrm{Ny}-\mathrm{i}$, míg hosszirány gyakoriság alapján az ÉK-DNy-i. A lineamensek mind a két esetben ÉNy-DK-i irányúak (2. ábra).

A völgyek hosszirány gyakorisága és a lineamensek irány- és hosszirány gyakorisága nem mutat kapcsolatot sem a szakirodalomból ismert vetők, sem a mért szerkezeti elemek csapásirányával. A völgyek iránygyakoriságának esetében megjelenő ÉK-DNy-i irány mutat kapcsolatot a térképezett szerkezeti elemek csapásával.

\subsection{Felsőtárkány - Dolomit bánya}

A felsőtárkányi Táltos Park Hotelhez vezető útról DK felé lekanyarodó turista/erdészeti út visz a várhegyi kőfejtőhöz, mely középső-triász (anisusi) korú szürke, sötétszürke rétegzetlen, sok esetben szingenetikusan breccsás megjelenésü, padokon belül finomrétegzett dolomitot (Hámori Dolomit Formáció) tár fel [9]. Petrik A. [10] a bányában É-D-i csapású kőzetréseket és néhány hasonló csapású, valamint ÉK-DNy-i és K-Ny-i csapású normálvetőket azonosított. A bánya 2 km-es környékén nagyrészt ÉK-DNy-i és erre merőleges csapásirányú szerkezeti elemeket térképeztek [9, 10].

A bányában - hasonlóan Petrik A.-hoz [10] - mi is zömében É-D-i csapású kőzetréseket és vetőket azonosítottunk, amelyek irányában $\mathrm{kb} \sim 40^{\circ}$-os ingadozás tapasztalható. Ezen kívül még egy $\mathrm{K}-\mathrm{Ny}$-i és ÉNy-DK-i irányú kőzetrésrajt sikerült elkülönítenünk (2. ábra). A feltárás környékén a völgyek iránygyakoriság alapján nem mutatnak irányítottságot. A lineamensek esetében legalább $50^{\circ}$-os irányszög ingadozást figyelhetünk meg, de feltételezhető egy ÉNy-DK-i irány. Hosszirány gyakoriság alapján a völgyek ÉÉK-DDNy-i, míg a lineamensek ÉNy-DK-i futásúak (2. ábra).

A völgyek iránygyakoriságának legjellemzőbb iránya és a szerkezeti elemek csapásiránya között nincs kapcsolat, a lineamensek esetében enyhe kapcsolat feltételezhető, ám a nagy szórás miatt ezt kétséget kizáróan nem lehet bizonyítani. A völgyek és lineamensek hosszirány gyakoriságának modális értéke áll közel a terepen mért ÉNy-DK-i csapású kőzetrés/vetőrajhoz, illetve a hasonló csapásirányú térképezett szerkezeti elemekhez.

\subsection{Szarvaskő - Tóbérci kőfejtő}

A Szavaskő határában található kőfejtőben az Alp-Kárpáti-Dinári-rendszer összetett fejlődéstörténetébe pillanthatunk bele. A bánya a Szarvaskői takaró mélytengeri sziliciklasztos kőzeteibe benyomult középső-jura (bath-callovi) korú gabbrót (Tardosi Gabbró Formáció) és differenciációval kialakult plagiogránit testet/testeket tár fel $[14,15]$. 
Pecsmány, P., Hegedüs, A.

Völgyek és lineamensek kapcsolata a szerkezeti elemekkel

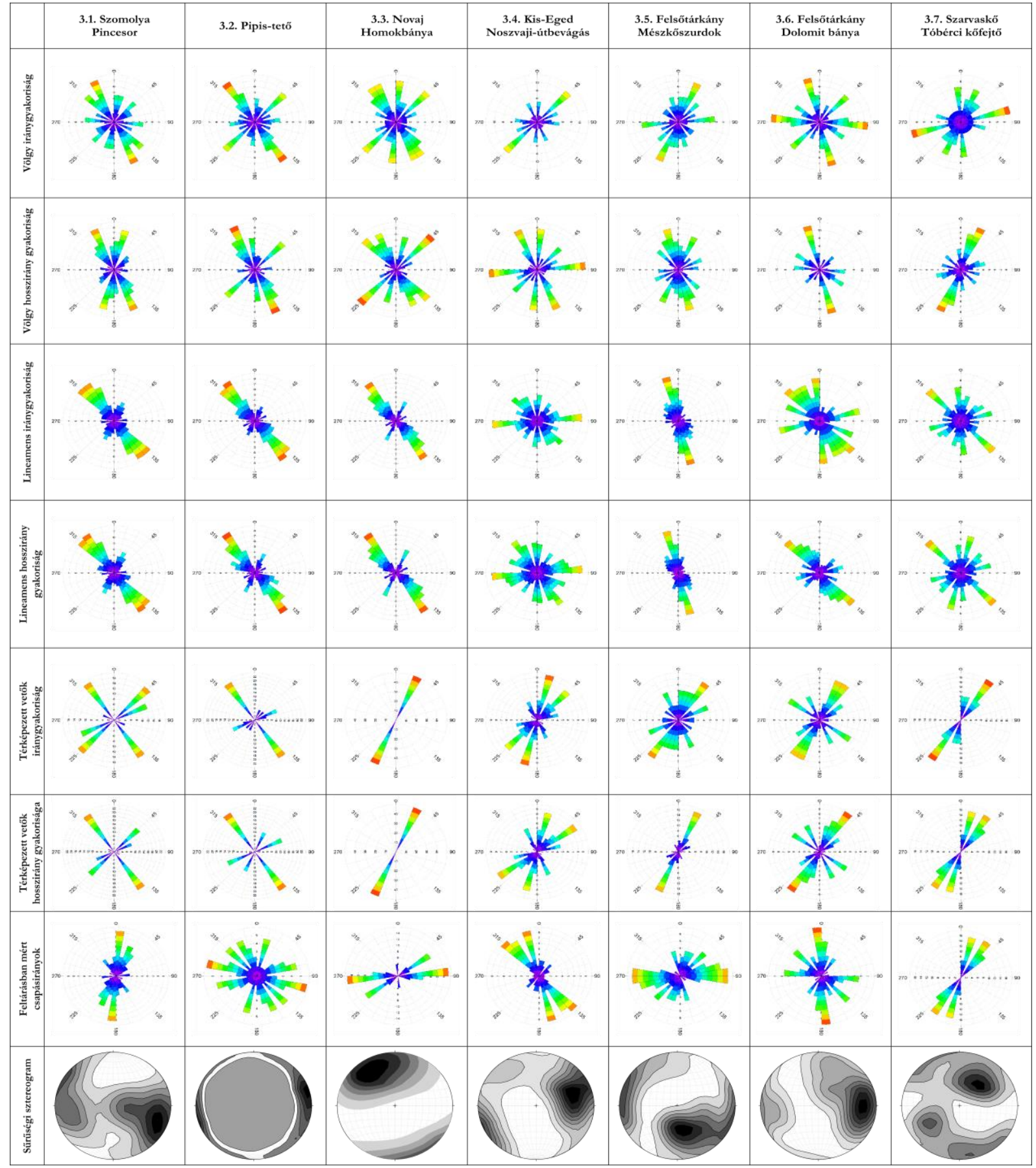

2. ábra. Mérési eredmények (3.1 - 3.7)

A köfejtő 2 km-es környékén zömében ÉÉK-DDNy-i és ÉK-DNy-i csapásirányú vetőket térképeztek $[9,10]$. 
A bányában mért adatok alapján a sztereogram és a rózsadiagram felhasználásával három vetörajt különítettünk el. Az első kettő egymással szimmetrikus, ebből kifolyólag csapásirányuk azonos, $\mathrm{K}-$ Ny-i. A harmadik vetőraj ÉNy-DK-i irányú, de $\sim 40^{\circ}$-os irányszög változékonysággal bír (2. ábra).

A völgyek iránygyakoriság alapján zömében KÉK-NyDNy-i irányba futnak, jelentős mellékirányként jelenik meg még az É-D-i és az ÉÉK-DDNy-i irány is. Ez utóbbi a hosszirány gyakoriság modális értéke. A lineamensek futásának leggyakoribb iránya mind a két esetben ÉNy-DK-i (2. ábra).

A völgyek iránygyakoriságának értéke nagyjából megegyezik a terepen mért K-Ny-i irányú vetőraj csapásirányával, míg a völgyek hosszirány gyakoriságának a modális értéke a térképezett ÉK-DNy-i csapású szerkezeti elemekkel hozható összefüggésbe. A lineamensek irány- és hosszirány gyakoriságának modális értéke jól követi a mért ÉNy-DK-i csapású vetőraj irányát. A lineamensek hosszirány gyakoriságánál megjelenő ÉK-DNy-i mellékirány pedig jól igazodik a térképezett szerkezeti elemek irányához.

\subsection{Almár-patak völgye}

Az Almár-patak völgye a jura korú képződmények mellett miocén (szarmata) korú, áthalmozott bélyegeket mutató riolittufát is feltár [9]. Gál Péterrel közös földtani térképezési munkánk során a miocén piroklasztitokban észlelhető szerkezeti elemeket, illetve rétegdőlést mértünk. A feltárás $2 \mathrm{~km}$-es környékén ÉK-DNy-i és ÉNy-DK-i csapásirányú szerkezeti elemeket térképeztek [9, 10]. A völgyben található kisebb feltárásokban mi is hasonló csapásirányú szerkezeti elemeket észleltünk (3. ábra).

A völgyek irány és hosszirány gyakoriság szerint is nagyrészt ÉNy-DK-i irányba futnak. A lineamensek iránygyakoriság alapján NyÉNy-KDK-i futásúak, illetve még elkülöníthetünk egy második, É-D-i mellékirányt is. Hosszirány gyakoriság alapján a lineamensek modális értéke NyÉNyKDK-i irányú (3. ábra).

A völgyek irány- és hosszirány gyakoriságának modális értékei jól követik a mért és térképezett ÉNy-DNy-i csapású szerkezeti elemeket. A lineamensek iránygyakorisága inkább már a térképezett szerkezeti elemek csapásirányával hozható kapcsolatba. Hosszirány gyakoriság alapján, a jelentős szórás miatt, csak sejthető a kapcsolat, azonban nem egyértelmü.

\subsection{Berva bánya}

Egertől ÉK-i irányba, a Berva-bércen található kőfejtő biogén, zátony és ciklikus lagúna környezetben képződött középső-triász (karni-ladin) korú mészkövet (Bervai Mészkő Formáció) tár fel [9]. Petrik A. [10] a Berva blokkban számos K-Ny-i csapásirányú normálvetőt észlelt. Katona G. [16] K-Ny-i, ÉKDNy-i és néhány ÉNy-DK-i csapásirányú oldaleltolódást és normálvetőt észlelt. A bánya $2 \mathrm{~km}$-es környékén ÉK-DNy-i és É-D-i irányú szerkezeti elemeket térképeztek [9, 10].

A bányában sajnos nem volt lehetőségünk észlelni, azonban a bánya bejáratának közelében számos feltárás található. Ezen feltárásokban zömében $\mathrm{K}-\mathrm{Ny}$-i és néhány ÉK-DNy-i csapásirányú szerkezeti elemet észleltünk. Az előbbiek csoportja $\sim 50^{\circ}$-os irányszög változékonysággal rendelkezik (3. ábra).

A feltárás környékén a völgyek iránygyakoriság alapján nem mutatnak irányítottságot. Hosszirány gyakoriság alapján a nagy részük ÉÉNy-DDK-i irányba fut. A lineamensek iránya jelentős szögváltozékonysággal rendelkezik. Összességében elmondható, hogy a lineamenseknél mind a két statisztikai esetben nagyrészt É-D-ies és ÉK-DNy-ias irányok dominálnak (3. ábra).

A völgyek iránya és a szerkezeti elemek csapásiránya között nem mutatható ki kapcsolat. A lineamensek É-D-ies és ÉK-DNy-ias irányai a térképezett szerkezeti elemekkel állhatnak kapcsolatban. 


\subsection{Andornaktálya - pincesor}

Andornaktályán, az Eger-patak K-i völgyközi háta miocén (kárpáti) korú, horzsaköves, freatomagmás riolittufájába (Gyulakeszi Riolittufa Formáció) [9] számos borospince(sor) mélyül. Méréseinket a Szállás-völgytől É-ra található pincesoron végeztük. Petrik A. [10] a közeli riolittufában nagyrészt ÉNy-DK-i irányú szerkezeti elemeket (karc nélküli vetőket, jobbos eltolódásokat) észlelt. A pincesor 2 km-es körzetében ÉK-DNy-i csapásirányú szerkezetet térképeztek $[9,10]$. A pincesoron zömében É-D-i csapásirányú kőzetréseket észleltünk. A kőzetrésraj közel $\sim 60^{\circ}$-os irányszög ingadozást mutat (3. ábra).

A völgyek iránygyakoriság alapján nem mutatnak irányítottságot. Hosszirány gyakoriság alapján zömében K-Ny-i irányba futnak, de hangsúlyosan megjelenik az ÉÉNy-DDK-i irány is. A lineamensek irány- és hosszirány gyakoriságánál az ÉNy-DK-i irány a domináns, illetve megjelenik az ÉÉNyDDK-i mellékirány is (3. ábra).

A völgyek nem mutatnak kapcsolatot, sem a kitérképezett, sem a mért szerkezeti elemek csapásirányával, azonban a lineamensek esetében megjelenő ÉÉNy-DDK-i irány kapcsolatban állhat a terepen mért kőzetrések csapásirányával.

\subsection{Egerbakta - tufakőfejtő}

Az Egerbaktától ÉNy-i irányba, a Felső-Mezőnél található felhagyott kőfejtő miocén (bádeni) horzsaköves blokktartalmú lapillitufát, tufát (dácit-riodácit) és összesült ignimbritet tár fel (Felnémeti Riolittufa Formáció a teljes geokémiai vizsgálatok alapján, az új besorolás szerint a Demjéni Ignimbrit Egységbe tartozik). A bányában kalcitos-mangánoxidos gömbkonkréciókat találtunk, melyek jelentős hányada töréses szerkezeti elemhez kapcsolódik [17]. Petrik A. [10] Egerbakta egyik tufabányájában É-D-i irányú normálvetőket, később ezeken kialakult jobbos eltolódásokat és kőzetréseket észlelt. A bánya 2 km-es környékén NyÉNy-KDK-i csapásirányú szerkezeti elemeket térképeztek eddig [9, 10].

A bányában mért szerkezeti elemek esetében egy ÉÉNy-DDK-i, egy NyÉNy-KDK-i és egy ÉKDNy-i csapásirányt lehet elkülöníteni (3. ábra).

A völgyek iránygyakoriság alapján nagyrészt ÉÉNy-DDK-ies irányúak, míg hosszirány gyakoriság alapján NyDNy-KÉK-i futásúak. A lineamensek mind a két esetben $\mathrm{K}-\mathrm{Ny}$-i irányt mutatnak (3. ábra).

A völgyek iránygyakoriságának legjellemzőbb értéke jól követi a terepen mért ÉÉNy-DDK-i közetrések csapásirányát. A völgyek hosszirány gyakorisága, valamint a lineamensek irány- és hosszirány gyakorisága nem köthető a szerkezeti elemek csapásirányához.

\subsection{Egerszalók - Kaptárkövek és környéke}

Egerszalókon, a Laskó-patak Ny-i völgyközi hátán található kaptárkövek miocén (kárpáti) korú riolittufát: horzsaköves blokktartalmú lapillitufát, tufát - nem összesült ingimbritet tárnak fel [12]. Petrik A. [10] Egerszalók környékén zömében ÉNy-DK-i és ÉK-DNy-i csapásirányú kőzetréseket és vetőket észlelt. A kaptárkövek 2 km-es sugarú környékén nagyrészt ÉK-DNy-i csapásirányú töréses szerkezeti elemeket térképzetek $[9,10]$.

A rózsadiagram és a sztereogram alapján két jelentős csapásirányt egy KÉK-NyDNy-it és egy ÉÉNy-DDK-iest lehetett elkülöníteni a mért szerkezetek esetébe (3. ábra).

A völgyek iránygyakoriság alapján ÉÉNy-DDK-i futásúak, hosszirány gyakoriság alapján a domináns irány NyÉNy-KDK, azonban megjelenik még két jelentősebb mellékirány is (ÉÉK-DDNy, ÉKDNy). A lineamensek mind a két esetben ÉNy-DK-i futásirányúak (3. ábra). 
Völgyek és lineamensek kapcsolata a szerkezeti elemekkel

\begin{tabular}{|c|c|c|c|c|c|c|}
\hline & $\begin{array}{l}\text { 3.8. Almár-patak } \\
\text { völgye }\end{array}$ & 3.9. Berva bánya & $\begin{array}{l}\text { 3.10. Andornaktálya } \\
\text { pincesor }\end{array}$ & $\begin{array}{l}\text { 3.11. Egerbakta } \\
\text { köfejtö }\end{array}$ & $\begin{array}{l}\text { 3.12. Egerszalók } \\
\text { Kaptárkövek és kôrnyéke }\end{array}$ & $\begin{array}{l}\text { 3.13. Demjén } \\
\text { Nagyeresztvény }\end{array}$ \\
\hline 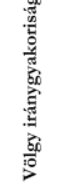 & $\frac{1}{7}$ & $\frac{1}{1}$ & ${ }^{2}$ & . & ${ }^{n} \cdots$ & : \\
\hline 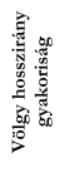 & 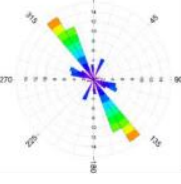 & 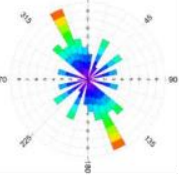 & 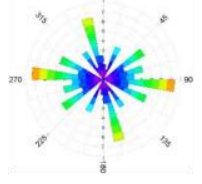 & (1) & (1) & $\sqrt{3}$ \\
\hline 党 & $\frac{1 / 4}{3 / 2}$ & $\frac{1}{4}$ & 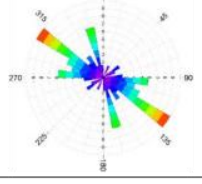 & का & in & की \\
\hline $\begin{array}{l}0 \\
0\end{array}$ & $-{ }_{8}^{1 / 4}$ & $y^{3}$ & $\prod_{8}^{1}$ & की & $\vdots$ & 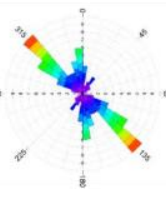 \\
\hline $\begin{array}{l}0 \\
0\end{array}$ & & $\times 2^{2}$ & : & ל.... & $\begin{array}{l}1 \\
0 \\
0\end{array}$ & (1) \\
\hline 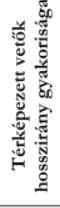 & 8 & 8 & $: \vdots$ & $\frac{1}{4}$ & 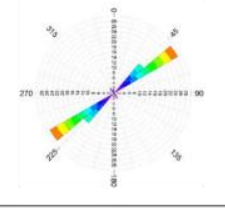 & 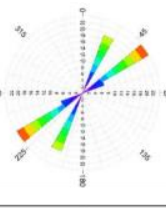 \\
\hline 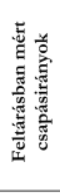 & 1 & $\begin{array}{r}7 \\
+\quad \vdots \\
\\
\end{array}$ & ${ }^{20} \cdots \cdots+$ & $\frac{\sqrt{1}}{1+}$ & 要 & (1) \\
\hline 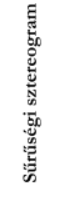 & & & & & & \\
\hline
\end{tabular}

3. ábra. Mérési eredmények (3.8 - 3.11)

A völgyek iránygyakoriságának legjellemzőbb iránya, míg hosszirány gyakoriság alapján megjelenő ÉÉNy-DDK-i mellékirány jól követi a kőzetrések csapásirányát. A lineamensek iránya a térképezett szerkezeti elemek ÉNy-DK-i, második leggyakoribb irányával állhat kapcsolatban, azonban ez az 
irány a hosszirány gyakorisági diagramon már meg sem jelenik, így a kontaktus erősen megkérdőjelezhetö.

\subsection{Demjén - Nagyeresztvényi bánya}

Demjén ÉK-i részén, a termálfürdőtől DK-i irányba található Nagyeresztvényi kőfejtő földtani értelemben a terület egyik legjobban feltárt része. A bánya miocén (bádeni) korú dácit-riodácit kőzeteket: horzsaköves blokktartalmú lapillitufát, tufát, gyengén összesült ignimbritet tár fel (Demjéni Ignimbrit Egység) [12]. Petrik A. [10] a kőfejtőben összetartozó É-D-i jobbos és K-Ny-i csapásirányú balos eltolódást észlelt. A jobbos eltolódások csapásiránya ÉNy-DK és ÉK-DNy között változik. A feltárás 2 km-es környékén ÉK-DNy-i és ÉÉK-DDNy-i csapásirányú szerkezeti elemeket térképeztek [9, 10].

A bányában, Petrik A.-val [10] nagyjából összhangban mi is NyÉNy-KDK-i, ÉNy-DK-i és É-D-i csapásirányú szerkezeti elemeket mértünk (3. ábra).

A völgyek irány- és hosszirány gyakoriság alapján is É-D felé futnak. A lineamensek zömében ÉNy-DK-i irányúak (3. ábra).

A völgyek modális iránya a mért szerkezeti elemek É-D-i csapású vetőrajával állhat kapcsolatban. A lineamensek modális iránya a terepen mért ÉNy-DK-i csapásirányú szerkezeti elemekkel mutat jelentösebb kapcsolatot.

\section{Eredmények}

A vizsgálat során 13 mérési pont $2 \mathrm{~km}$-es sugarú körében vetettük össze a mért és térképezett szerkezeti elemek csapásirányát a völgyek és lineamensek futásirányával. Ha a völgyek és lineamensek esetében csak a domináns irányokat vesszük figyelembe, akkor a következö következtetéseket lehet levonni.

A mért szerkezeti elemek csapásiránya és a völgyek iránygyakorisága között az esetek 38,46\%-ban, a völgyek hosszirány gyakorisága esetében pedig 30,77\%-ban találtunk egyezést. A térképezett szerkezeti elemek csapásiránya és a völgyek iránygyakorisága között, hasonlóan az elözőkhez, az esetek 38,46\%-ban volt megfigyelhető egyezés, míg a hosszirány gyakoriságnál 46,15\%-ban (4. ábra).

A mért szerkezetek csapása és a lineamensek iránygyakorisága között az esetek 15,38\%-ban, míg hosszirány gyakoriságánál az esetek 23,08\%-ban volt megfigyelhető kapcsolat. A térképezett szerkezeti elemek esetében ez az arány valamivel jobb. A lineamensek irány- és hosszirány gyakoriságánál is az esetek 30,77\%-ban volt megfigyelhetö összefüggés a szerkezeti elemek csapásirányával (4. ábra).

Összességében elmondható, hogy a völgyek iránygyakoriságánál az estek 69,23\%-ban, hosszirány gyakoriságánál az esetek 53,84\%-ban, a lineamensek iránygyakoriságánál az esetek 53,84\%-ban, míg hossziránygyakoriságánál az esetek 46,15\%-ban volt egyezés a szerkezeti elemek csapásirányával (4. ábra).

Ha az irány- és hossziránygyakoriságot egynek tekintjük, akkor a völgyek domináns iránya az esetek 84,62\%-ban, míg a lineamensek domináns futásiránya az esetek 53,85\%-ban volt köthető valamelyik (mért, térképezett) szerkezeti elem csapásirányához (4. ábra).

A vizsgálataink alapján elmondható, hogy a Bükk délnyugati elöterének szerkezetfejlődése alapvetően befolyásolta a felszínfejlődését és a völgyhálózat kialakulását, azonban lokálisan eltérések voltak tapasztalhatók. 


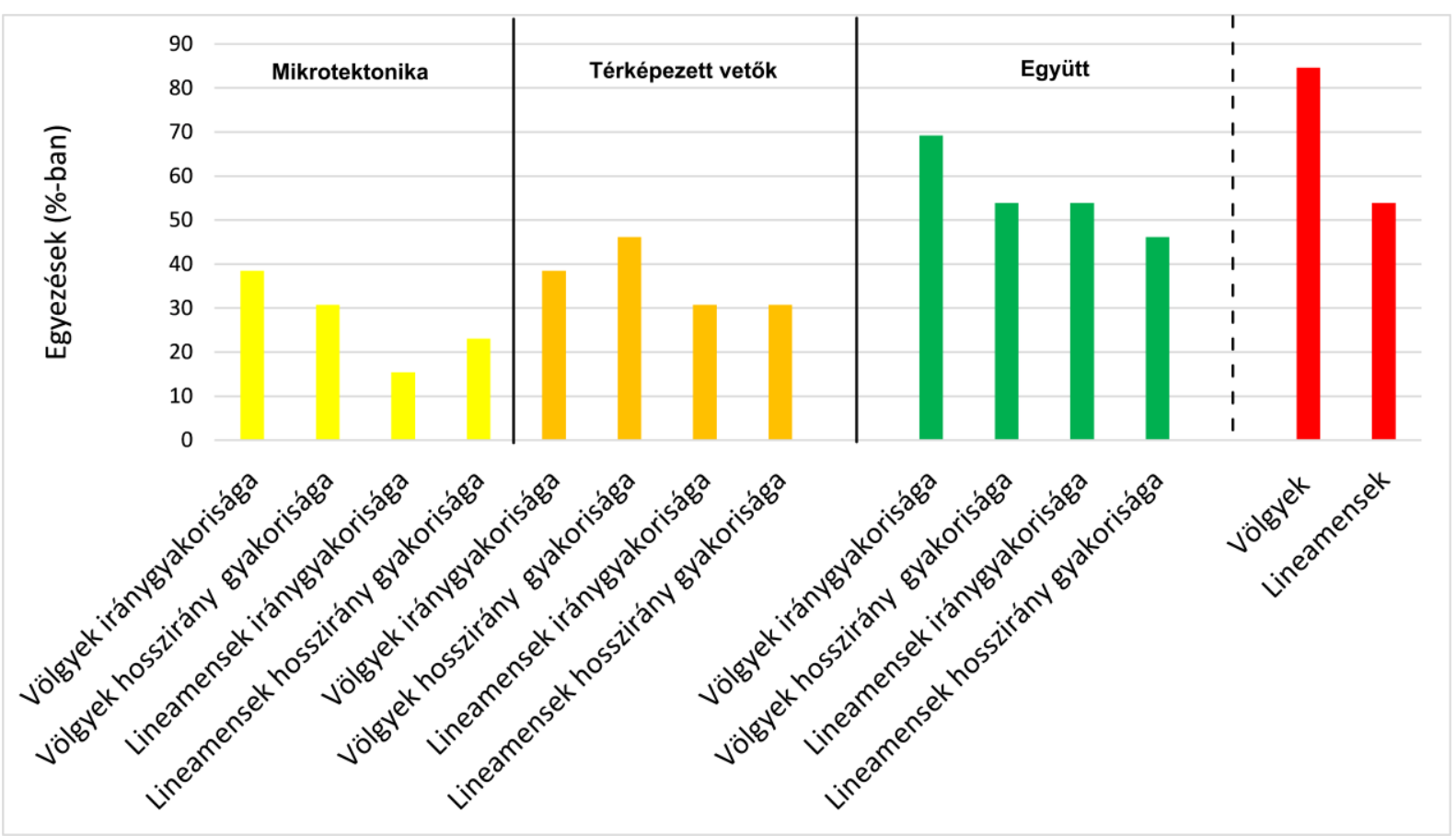

4. ábra. Völgyek és lineamensek modális irányának egyezése a mért és térképezett szerkezeti elemek irányával

\section{Köszönetnyilvánítás}

A cikkben ismertetett kutató munka az EFOP-3.6.1-16-2016-00011 jelű „Fiatalodó és Megújuló Egyetem - Innovatív Tudásváros - a Miskolci Egyetem intelligens szakosodást szolgáló intézményi fejlesztése" projekt részeként - a Széchenyi 2020 keretében - az Európai Unió támogatásával, az Európai Szociális Alap társfinanszírozásával valósul meg.

\section{Irodalom}

[1] Egyed, L.: Vizfolyások, morfológia és tektonika kapcsolata, Földtani Közlöny, 87 (1) (1957) pp. 69-72.

[2] Gábris, Gy.: A vízhálózat szerkezeti összefüggései, Földtani Közlöny, 116: (1986) pp. 45-56.

[3] Watson, G. S.: Orientation statistics in the Earth Science, Acta Univ. Upsaliensis (2) (1970) 73. p.

[4] Demeter, G., Szabó, Sz.: A völgyhálózat és törésirányok kapcsolatának vizsgálata különbözö geoinformatikai módszerekkel a Bükk északi előterén, HunDEM 2009 és GeoInfo 2009 Konferencia, Miskolc, pp. 1-20.

[5] Petrik, A., Jordán, Gy.: Systematic Digital Terrain Model construction and model verification with multi-source field data, Morphotectonic analysis in the Villany Hills and its surroundings, SW Hungary, Carpathian Journal of Earth and Environmental Sciences 12(1) (2017) pp. 207224.

[6] Schréter, Z.: Az 1925 január 31 -i egri földrengés, Földtani Közlöny, 55. (1926) pp. 26-49. 
[7] Schréter, Z.: A Bükk-hegység délkeleti oldalának földtani viszonyai, 1932-34, Magyar Királyi Földtani Intézet évi jelentése, (1933) pp. 511-526.

[8] Balogh, K.: A Bükk-hegység és környékének földtani térképe 1: 100 000, MÁFI, 1963

[9] Less, Gy., Kovács, S., Pelikán, P., Pentelényi, L., Sásdi, L.: A Bükk-hegység földtana, Magyarázó a Bükk hegység földtani térképéhez (1:50 000), 2005, ISBN 9636712530

[10] Petrik, A.: A Bükk déli elöterének kainozoos szerkezetalakulása, (Cenozoic Structural Evolution of the Southern Bükk Foreland), PhD Thesis, ELTE-TTK, Budapest, (2016) 264.p.

[11] Al-Obeidat, F., Feltrin, L., Marir, F.: Cloud-based lineament extraction of topographic lineaments from NASA Shuttle Radar topography mission data, Procedia Computer Science 83. (2016) pp. 1250-1255. https://doi.org/10.1016/j.procs.2016.04.260

[12] Lukács, R., Harangi, Sz., Guillong, M, Bachmann, O., Fodor, L., Buret, Y., Dunkl, I., Sliwinski, J., von Quadt, A., Peytcheva, I., Zimmerer, M.: Early to Mid-Miocene syn-extensional massive silicic volcanism in the Pannonian Basin (East-Central Europe): Eruption chronology, correlation potential and geodynamic implications, Earth-Science Reviews, 179 (2018) pp. 119. https://doi.org/10.1016/j.earscirev.2018.02.005

[13] Dávid, Á.: Paleontológia, EKF - főiskolai jegyzet, (2011) pp. 31-33.

[14] B. Kiss G., Zagyva, T.: Jura idöszaki magmás közetek Szarvaskön, 2017 8. Közettani és Geokémiai Vándorgyülés, Szihalom, pp. 194-196. ISBN: 9789636713119

[15] Kovács, Z., Kövér, Sz., Fodor, L., Schuster, R.: Új SM/ND koradat a Tóbérclápai-köfejtö plagiogránit gránátjából, 2017 8. Közettani és Geokémiai Vándorgyülés, Szihalom, pp. 97-98. ISBN: 9789636713119

[16] Katona, G.: Preliminary analysis of heterogeneous fault-slip systems in the Felnémet Limestone Quarry, 2017 Doktoranduszok Fóruma, Miskolci Egyetem, pp. 33-41.

[17] Gál, P., Pecsmány, P., Lukács, R., Czuppon, G., Surányi, G., Polgári, M., Harangi, Sz.: Kalcitos-mangán-oxidos gömbkonkréciók bükkaljai piroklasztitokban, 2018 9. Közettani és Geokémiai Vándorgyülés, Mátraverebély, pp. 55-56. ISBN: 9789638221728 